\title{
Introduktion
}

\section{Resultatstyring dengang og i dag: Version 2.0, 3.0, 4.0?}

\author{
Marie-Louise Frølich Brødsgaard stud.scient.pol, Institut for Statskundskab, Københavns Universitet \\ Mathias Gjørling stud.scient.pol, Institut for Statskundskab, Københavns Universitet \\ Caroline Howard Grøn ph.d., adjunkt, Institut for Statskundskab, Københavns Universitet \\ Mads Bøge Kristiansen ph.d., post.doc., Institut for Statskundskab, Københavns Universitet
}

At runde de 30 er på mange måder et skarpt hjørne. Det er en alder, hvor man så småt oplever, at man for alvor bliver stillet til regnskab for egne handlinger. 30, så begynder man at skulle være voksen. Men hvordan ser det så egentlig ud, hvis man er er et styringsredskab? Hvis et styringsredskab har 30 år på bagen, kan vi så forvente, at det efterhånden er implementeret på en måde, så det virker efter hensigten? Kan vi forvente, at børnesygdomme og ungdommens fejldispositioner er bag det? Resultatstyring har været på styringsdagsordenen siden 1983. I dag, som gennem 1980'erne og 1990'erne, er forventningerne til, hvad resultatstyring kan levere, høje. I dette temanummer er vi interesserede $\mathrm{i}$, hvordan tænkningen om resultatstyring har udviklet sig igennem de sidste 30 år. Er forventningerne til, hvad resultatstyring kan levere, de samme i dag som i 1980'erne? Og så er vi interesserede i, hvorfor resultatstyring stadig præsenteres som løsningen på den offentlige sektors styringsproblemer efter 30 år? Hvorfor implementerede de det ikke bare i 1980'erne? Kort sagt er vi interesserede i, hvad det er ved resultatstyring, der gør det så svært at implementere, at vi stadig prøver efter 30 år.

Resultatstyring spiller en central rolle i offentlig styring i Danmark, og har gjort det i snart tre årtier. Selvom resultatstyring kan betegnes som: as old as public administration itself (Pollitt \& Bouckaert 2011, 106), så begyndte resultatstyring for alvor at manifesterer sig i den danske offentlige sektor i løbet af 1980'erne og 1990'erne. I 1983 lød det således i regeringens moderniseringsprogram: ${ }^{1}$

\begin{abstract}
„Moderniseringsprogrammet er udtryk for nytænkning omkring den offentlige sektors måde at fungere på. Det er en nytænkning, som tager sigte på at ændre det offentliges interne styringssystemer, procedurer og spilleregler. Programmet forudsætter samtidig et holdningsskift, med vægt på at sikre tidssvarende ydelser og en god betjening af det offentliges kunder uden tilførsel af nye ressourcer. Med henblik herpå henstiller regeringen, at de enkelte styrelser, institutioner og øvrige administrative enheder opstiller mål for de tilstræbte kvalitetsforbedringer og løbende vurderer resultaterne, således som det allerede praktiseres i f.eks. DSB og P\&T.“ (Vores markering)
\end{abstract}

I løbet af de seneste 30 år har resultatstyring i et eller andet omfang spredt sig til snart sagt alle kroge af den offentlige sektor. Der tales om resultater og effekter som aldrig før. Som et resultat heraf er resultatstyring blevet en del af de fleste offentlige organisationers hverdag. Der udarbejdes årsrapporter og scorecards, der benchmarkes, offentliggøres rankinglister osv. Alt sammen for at styre efter og informere om resultaterne af offentlige organisationers indsatser (Kristiansen 2014, 15). Men selvom resultatstyring nu har godt tre årtier på bagen, er konceptet ikke blevet mindre populært. Hvis man ser i SSF-R-regeringens regeringsgrundlag (Regeringen 2011), regeringens vækstplan (Regeringen 2013), regeringens nationale reformprogram (Regeringen 2014) eller i pro- 
duktivitetskommissionens slutbetænkning (Produktivitetskommissionen 2014), er der fortsat en stor tiltro til resultatstyringens potentialer:

$$
\begin{aligned}
& \text { „Øget fokus på resultater vil skabe rum for } \\
& \text { større fagligt ansvar og give plads til moderne } \\
& \text { ledelsesformer og øget nytænkning. Det vil } \\
& \text { forbedre kvaliteten og frigøre ressourcer til } \\
& \text { bedre service for borgerne, og det vil gøre } \\
& \text { faglig stolthed og arbejdsglæde til drivkraft i } \\
& \text { udvikling af servicen til borgerne“ (Regerin- } \\
& \text { gen 2011, 63). }
\end{aligned}
$$

Forventningerne er store, og resultatstyring bliver til stadighed fremhævet som et af de helt centrale virkemidler, når den offentlige sektor skal gøres mere produktiv, effektiv, gennemsigtig eller ansvarlig.

Vores ambition med temanummeret er at få en bedre forståelse af, hvorfor et styringsfænomen, der har været på dagsordenen i 30 år, omgivet af store forventninger, stadig er at finde i toppen af denne dagsorden på trods af et noget blakket karakterblad.

For at gøre det vil denne indledning indeholde fire afsnit. Først præsenterer vi vores forståelse af resultatstyring og den styringstænkning, resultatstyring som fænomen skriver sig ind i. Dernæst ser vi nærmere på, hvordan vi kan forstå resultatstyring som en styringsopskrift, der spreder sig. På baggrund af den diskussion præsenterer vi temanummerets opbygning og indhold. Endelig giver vi i det afsluttende afsnit et bud på, hvorfor det er så svært at høste de forventede gevinster af resultatstyring, og på den baggrund hvorfor vi stadig forsøger at implementere det.

\section{Resultatstyring defineret}

Vi vil her forsøge at præsentere en idealtypisk definition af resultatstyring. Som brugen af begrebet idealtype indikerer, er der tale om en logisk sammenhængende beskrivelse af fænomenet, der lægger vægt på at præsentere en definition af resultatstyring, der ikke nødvendigvis afspejler virkelige manifestationer af fænomenet, men i stedet kan bruges til analytiske formål (Weber 1968, 190). Resultatstyring trækker på en bestemt form for styringstækning, der kan beskrives som instrumentel og målorienteret. Mere specifikt kan en række antagelser i tænkningen fremhæves:

Målantagelsen: Styring opfattes som målorienteret. ${ }^{2}$

Indsatser foretages med henblik på at indfri fastsatte mål.

Intentionalitetsantagelse: Individer og organisationer er intentionelle, de kan orientere sig efter opstillede mål og handle strategisk i forhold til dem. Organisationer og individer kan lære af deres tidligere indsatser og blive bedre til i fremtiden at opnå deres mål, hvis de forholder sig til resultaterne af tidligere indsatser. Tilsvarende kan individer og organisationer forholde sig til kontrol af deres indsats, hvis de ved, de bliver kontrolleret, kan de styre deres handlinger i en retning, så de kan møde kontrollens krav.

Kausalitetsantagelsen: Der er en sammenhæng mellem indsats og resultat. Når organisationen opnår givne mål, er det en konsekvens af bevidste handlinger.

Koblingsantagelsen: Organisationer antages at være tæt koblede. Det skal forstås på to dimensioner. For det første er det muligt at koordinere i organisationer. Ledelsen kan vedtage mål og igennem styring sikre sig, at de bliver opfyldt i organisationens yderste led. For det andet er det ikke sådan, at organisationer per definition er areaner for magtkampe. Deraf følger, at der ikke er noget i organisationens natur, der gør, at målopfyldelse bliver svær. Hvis der er konflikter, bunder de i forkerte incitamenter.

Når man ser på disse antagelser, forekommer de måske lidt intetsigende. Det kan derfor være vigtigt at gøre klart, hvilke antagelser om styring der $i k k e$ er til stede i denne optik. For det første spiller usikkerhed en overkommelig rolle i denne tilgang. Usikkerhed er et leitmotif i organisationsteorien ( $f_{x}$ Galbraith 1977 eller Weick 2001). Resultatstyring kommer med en antagelse om, at vi kan styre os ud af usikkerheden og tilskrive ansvar, ligesom resultatstyring forventer at styringstiltag har kausal-lignende effekter. For det andet er individer og organisationer intentionelle. De er ikke kognitivt overbelastede (jf. Weick 2001) og individernes nyttemaksimering gør det heller ikke svært at styre (Dixit 2002).

Disse antagelser udgør tilsammen det logiske bagtæppe for resultatstyring, der mere specifikt kan defineres som en type af styring baseret på resultatinformation. Den resultatinformation, som styringen baseres på, er produktet af en resultatmålingsproces, der består af en række aktiviteter, henholdsvis at fokusere målingsindsatsen, udvælge indikatorer, indsamle, analysere og rapportere data.

På den ene side er det en ganske bred definition af resultatstyring, idet den dækker over såvel målstyring, hvor resultater kobles til de på forhånd opstillede målsætninger, som sammenligningsbaseret resultatstyring, hvor opnåede resultater sammenlignes med andre (lignende) organisationers resultater (Hood 2007). På den anden side er det en definition, der stiller visse krav. Dette skal ses i lyset af, at definitionen betoner den aktive anvendelse af resultatinformation. Selvom den aktive anvendelse af resultatinformation er det afgørende element i definitionen af resultatstyring, er det ikke altid, at de organisationer, der arbejder med resultatstyring, når så langt i resultatstyringsprocessen. Der er mange ting, der kan gå galt 
Figur 1. Resultatstyringens faser

Fokusering af målingsindsats

\section{Valg af} indikatorer

\section{Indsamling af data}

\section{Analyse af data}

\section{Rapportering}

Anvendelse

af information i processen fra fokusering af målingsindsats (fx målformulering), over udvælgelse af indikatorer, indsamling af data, analyse og fortolkning af data, rapportering af data og til den egentlige anvendelse af resultatinformation. Vi kan altså opleve, at organisationer identificerer det, de gør, som resultatstyring, også selvom alle led i kæden ikke anvendes. Her bliver det vigtigt at huske, at vores definition her skal forstås som et idealtypisk udgangspunkt, vi skal anvende i undersøgelsen af institutionaliseringen af resultatstyring.

Selvom resultatstyring til stadighed fremhæves som løsningen på en række styringsproblemer i den offentlige sektor, er det ikke alle, der deler denne begejstring for resultatstyring. Fra kritikerenes side (fx Radin 2006; Bevan \& Hood 2006) påpeges det således, at implementeringen og anvendelsen af resultatstyring langt fra er problemfri. Vi ser med andre ord også i litteraturen en række udfordringer og barrierer på vejen mod realiseringen af styringsredskabets potentialer. Med dette temanummer ønsker vi at bidrage til denne diskussion og vender i slutningen af denne indledning tilbage til spørgsmålet om, hvad der står i vejen for at høste de forventede positive effekter af resultatstyring.

Som vi skrev i starten af afsnittet, er vores definition af resultatstyring idealtypisk. Vi er, i vores undersøgelse af resultatstyring derfor også interesserede i resultatstyringsmodeller, der i ikke honorerer alle de krav til et styringsværktøj, vi opstiller her. Det, vi er interesserede i, er, hvordan praksis kobler sig til ideen om resultatstyring, derfor skal vi i næste afsnit se lidt nærmere på den forståelse af spredning af styring, vi trækker på her.

\section{Spredning af styringsopskrifter}

Når vi taler om resultatstyring, taler vi om en idealtypisk styringsidé, der kan have mange forskellige empiriske manifestationer. Den sociologiske institutionalisme hjælper os til at forstå, at en styringsopskrift ${ }^{1}$ kan have ét indhold, mens den måde, den praktiseres på, kan have et andet (fx Meyer \& Rowan 1977). Når vi ser på resultatstyrings popularitet, kan man nærmest beskrive det som en rationaliseret myte i Meyer \& Rowans forstand (1977). Resultatstyring bliver taget for givet som vejen til større effektivitet, uafhængigt af de resultater, resultatstyring reelt har leveret.

Meyer \& Rowan eller Brunsson (2000) ville imidlertid også påpege, at spredning på det retoriske plan er en ting, mens spredning på praksisplanet er en anden. Vi er i dette temanummer interesseret $\mathrm{i}$, hvordan resultatstyring manifesterer sig på en række forskellige niveauer. Med udgangspunkt i Brunsson (2002) og Pollitt (2001; 2002) skelnes mellem analyser, der fokuserer på henholdsvis tale, beslutning, handling og resultater. Hvor første del af temanummeret fokuserer på tale- og beslutningsniveauet, vil den sidste del hovedsageligt fokusere på handlings- og resultatniveauet. Temanummerets stuktur og indhold er præsenteret i tabel 1.

Vi vælger denne tilgang, fordi vi på den ene side er interesserede $i$, hvordan resultatstyring som abstrakt opskrift har udviklet sig over tid. Vi ser her særligt på, hvordan Finansministeriet har forholdt sig til opskriften over tid. På den anden side er vi også interesserede i, hvordan resultatstyring som abstrakt opskrift omsættes til handlinger og resultater i den offentlige sektor. Vi føl-

Tabel 1. Temanummerets artikler i forhold til de fire typer af organisatorisk output

\begin{tabular}{|c|c|c|c|c|}
\hline & Tale & Beslutninger & Handlinger & Resultater \\
\hline $\begin{array}{l}\text { Artikel 1: Moderniseringsprogrammet, 1983: resultatstyring version } \\
1.0\end{array}$ & \multicolumn{2}{|c|}{$\begin{array}{l}\text { Den første tænkning om resultatstyring på } \\
\text { det statslige niveau }\end{array}$} & & \\
\hline $\begin{array}{l}\text { Artikel 2: Kontinuitet og forandring i statens mål- og resultatstyrings- } \\
\text { koncept }\end{array}$ & \multicolumn{2}{|c|}{$\begin{array}{l}\text { Udviklingen fra 1980'erne til i dag i det } \\
\text { statslige mål- og resultatstyringskoncept }\end{array}$} & & \\
\hline $\begin{array}{l}\text { Artikel 3: Fra resultatkontrakt til mål- og resultatplan: Ny inspiration til } \\
\text { realiseringen af resultatstyringens potentialer }\end{array}$ & \multicolumn{2}{|c|}{$\begin{array}{l}\text { De seneste revisioner af resultatstyrings- } \\
\text { konceptet på det statslige niveau }\end{array}$} & & \\
\hline Artikel 4: Hvorfor benchmarker kommunerne? & \multicolumn{4}{|c|}{ Brugen af benchmarking i kommunale forvaltninger } \\
\hline Artikel 5: Resultater ved fronten - brugen af effektstyring i dagtilbud & & & \multicolumn{2}{|c|}{ Implementering af resultatstyring i dagtilbud } \\
\hline
\end{tabular}


ger hermed de sociologiske institutionalisters antagelse om, at styringsopskrifter ikke „bare“ implementeres. De omformes, tilpasses, oversættes eller afkobles måske ligefrem i mødet med organisatorisk praksis (Meyer \& Rowan 1977; Brunsson 2002; Røvik 2007; Czarniawska \& Sevón 1996). ${ }^{2}$ Det er derfor interessant at forstå, ikke blot hvad „opskriften“ resultatstyring består af, hvordan der tales og besluttes om resultatstyring, men også hvordan resultatstyring omsættes til handling og resultater.

\section{Temanummerets opbygning og hovedkonklusioner}

I den første del af temanummeret ønsker vi at skrive historien om resultatstyring - eller mere præcist historien om mål- og resultatstyring i staten og dennes udvikling over tid. Vi ønsker at gøre klart, hvordan opskriften resultatstyring er opstået, og hvordan den er blevet meningsudfyldt af centrale aktører over tid.

I temanummerets første artikel interviewer Mathias Gjørling og Caroline Howard Grøn Carsten Jarlov, direktør i Bygningsstyrelsen, der var kontorchef i det kontor, som i 1983 udarbejdede moderniseringsprogrammet. ${ }^{3}$ Interviewet afdækker ideen bag moderniseringsprogrammet, det politiske spil, der omgav programmet, og programmets færdres forestillinger om, hvilken betydning programmet ville have for den danske offentlige sektor. Interviewet viser, at selvom moderniseringsprogrammet er blevet kaldt startskuddet til brugen af resultatstyring $\mathrm{i}$ staten, spiller resultater en beskeden rolle i programmet. Resultater optræder som en mulig implementeringsmekanisme frem for en central del af programmet, og placeringen af resultatstyring i programmets styringstænkning virker ret tilfældig.

Efter at have beskrevet tænkningen bag resultatstyringskonceptets indtog i den statslige sektor, ser vi nærmere på, hvordan konceptet har udviklet sig fra 1983 til i dag. Mads Bøge Kristiansen beskriver i sin artikel, hvorvidt det statslige resultatstyringskoncept som institution har været kendetegnet ved kontinuitet eller forandring. Med udgangspunkt i en historisk institutionel analyseramme identificeres og forklares forandringsmønstre i resultatstyringskonceptets udvikling over tid. Artiklen viser, hvordan resultatstyringsinstitutionen siden introduktionen overordnet har været kendetegnet ved stabilitet. På trods af denne overordnede stabilitet er mål- og resultatstyringsinstitutionen løbende blevet justeret og forandret (inden for den overordnede sti). Disse gradvise forandringer resulterer undertiden i ændringer i retningen for resultatstyringskonceptet; fra autonomi og et meget simpelt styringsredskab i de tidlige år mod mere kontrol og et mere omfattende mål- og resultatstyringssystem fra midten/slutningen af 1990 'erne og tilbage igen mod et mindre omfattende mål- og resultatstyringskoncept i de seneste år.

Den første del af temanummeret slutter af med et interview, hvor fokus er på det nyeste skud på stammen inden for det statslige resultatstyringskoncept. MarieLouise Frølich Brødsgaard og Mads Bøge Kristiansen interviewer to af de centrale aktører bag de seneste ændringer, Stig Henneberg ${ }^{4}$ og Nanna Skriver Dall fra Center for udgiftspolitik og modernisering i Finansministeriet. Interviewet blev gennemført i september måned 2014 umiddelbart efter lanceringen af den nye model. Interviewet fokuserer på baggrunden for revisionen af det eksisterende resultatstyringskoncept, hvad den nye model indeholder, samt hvorfor den nye model forventes at kunne løse de udfordringer, det statslige resultatstyringskoncept hævdes at være præget af. I den nye model har Finansministeriet anbefalet, at styringsdokumenterne skal indeholde færre, mere skarpt definerede mål og være forankret i topledelsen. Dette skal ses på baggrund af en udbredt opfattelse af, at resultatkontrakterne mange steder var blevet alt for omfattende, samtidig med at det var uklart, om de blev brugt som styringsredskab. Finansministeriets seneste revision kan derfor ses som et forsøg på at skabe nyt liv i den statslige mål- og resultatstyring, der mange steder opleves at være sandet til. Med revisionen af modellen forsøger Finansministeriet således at omgå nogle af de barrierer, der vurderes at være for indfrielsen af styringsredskabets potentialer. Finansministeriet søger med modellen at give inspiration til implementeringen af styringsredskabet i de enkelte ministerier. Samtidig kommer inspirationen til resultatstyring også fra mange andre sider end Finansministeriet. Det er derfor op til de enkelte ministerier, styrelser og institutioner at få omsat inspirationen i meningsfulde styringsdokumenter og styringspraksis på de respektive ministerområder.

Institutionen „resultatstyring“ er blevet defineret fra centralt hold på lidt varierende måder over tid. Man kan forstå den historiske udvikling som et forsøg på løbende at justere og tilpasse mål- og resultatstyringskonceptet med henblik på at imødegå nogle af de udfordringer, der opleves i forbindelse med brugen af værktøjet. Selvom kernen i værktøjet er fastholdt, er det via mindre forandringer løbende blevet forsøgt henholdsvis at forfine og forenkle styringsredskabet. Centrale dele af opskriften er altså bevaret, men der har også været løbende forandringer.

Temanummerets første del fortæller primært historien om, hvordan mål- og resultatstyring som opskrift er blevet tænkt over tid. I anden del af temanummeret ser vi nærmere på, hvordan institutionen resultatstyring bliver til handling og resultater. Vi er interesserede $\mathrm{i}$, hvordan institutionen gives indhold i praksis, men også hvorfor 
det har været så svært at høste de gevinster, resultatstyring har lovet. Tilbage til udgangspunktet: hvorfor er vi stadig i gang efter 30 å?

Først ser Marie-Louise Frølich Brødsgaard og Mathias Gjørling i deres artikel på 6-by-samarbejdet, et benchmarking samarbejde mellem Danmarks seks største bykommuner. I artiklen viser de, at kommunerne ikke indfrier egne forventninger til anvendelsen af samarbejdet og effekterne heraf. Der er ikke overensstemmelse mellem formål og den faktiske anvendelse; benchmarking er primært et fænomen, der påvirker tale og beslutninger og i mindre grad leder til faktiske handlinger. På denne baggrund diskuterer de, hvorfor kommunerne fortsat udarbejder nøgletallene, og vurderer, at den fortsatte udarbejdelse skyldes, at gevinsterne og omkostningerne ved produktionen er skævt fordelt, og at en gruppe af eliteaktører med magt til at kræve produktionen fortsat har nettogevinster ved samarbejdet.

Endelig ser temanummerets sidste artikel på det yderste niveau i styringskæden. Caroline Howard Grøn ser på, hvordan tanken om styring efter resultater implementeres på dagtilbudsområdet i Frederiksberg Kommune. Artiklen viser, hvor varieret pædagogerne handler med reference til resultatstyring. „Opskriften“ resultatstyring bliver omformet til noget nær ukendelighed, når den rammer den pædagogiske praksis, men bliver samtidig tilpasset målgruppens hverdag og verdenssyn. På den baggrund diskuteres, hvilke barrierer der er for implementeringen af effektstyring. Artiklen påpeger, at særligt fire ting gør forskellen mellem de institutioner, hvor effektstyring anvendes $i$ et vist omfang, og dem hvor det ikke gør. Disse institutioner er kendetegnet ved en klar ledelsesopbakning bag projektet, der er afsat tid til at pædagogerne kan arbejde med det, der er medarbejdere i institutionen, der tager ansvar for den lokale tilpasning, og endelig er der ikke konkurrerende dagsordner, der tager opmærksomheden.

Når vi ser på resultatstyring som en institutionaliseret opskrift, kan litteraturen som bekendt have forskellige forventninger til, hvordan opskriften vil materialisere sig. Det ændrer imidlertid ikke på, at resultatstyring i den offentlige diskurs tilskrives et stort effektiviserende potentiale. Derfor bliver det vigtigt at se på, hvorfor dette potentiale ikke altid indløses. Det er ikke nok at sige, at det er en rationaliseret myte. Vi vil gerne gå et skridt tættere på, og se på, hvordan det kan være, materialiseringen af resultatstyring ser så forskellig ud. Vi vælger at kalde det barrierer for implementeringen. På trods af den lidt kontraintuitive placering i starten af temanummeret vil vi opsummere de barrierer, vi ser, på tværs af temanummeret. Det er klart, at der her er tale om en ,impressionistisk øvelse“. Vi har ikke cases nok til at kunne afdække hele universet af potentielle barrierer for implementeringen af resultatstyring, selvom vi har cases på forskellige administrative niveauer. Vi har sammenholdt vores fund med litteraturen og kan dermed kvalificere vores fund. Imidlertid må listen nedenfor ikke tages som hverken udtømmende eller endelig.

\section{Barrierer for vellykket implementering af resultatstyring}

Overordnet er det en ganske vanskelig opgave at styre i den offentlige sektor. De sociologiske institutionalister påpeger på den baggrund risiko for afkobling; at en opskrift som resultatstyring faktisk aldrig rigtig bliver implementeret på en måde, så den kan forventes at virke.

Men der er også andre måder anskue styringsudfordringerne på. En måde, kunne være at se på opgaverne. De opgaver, der løses af offentlige organisationer, er komplekse, og der er ofte tale om „wicked problems“; problemer, der er svære at definere, og som hænger uløseligt sammen med andre problemer. Løsninger på „wicked problems" er aldrig er optimale, men et trade-off mellem forskellige aktørers interesser (Rittel \& Webber 1973). Samtidig er den offentlige sektor kendetegnet af beslutninger, der rejser igennem mange led, fra beslutningstagere træffer beslutning, til borgeren ser et resultat. På den baggrund er det vigtigt her at understrege, at andre styringsredskaber også kan have problemer med at styre den offentlige sektor, og at når man ser på et styringsværktøjs „track record“, må man holde sig for øje, at det generelt er svært at styre den offentlige sektor. Når det så er sagt, er der en række mere specifikke udfordringer for resultatstyring, som de enkelte artikler i dette temanummer påpeger. De identificerede barrierer og udfordringer er struktureret i forhold til aktiviteterne i resultatstyringsprocessen beskrevet i figur 1 .

Hvis vi starter med fokuseringen af målingsindsatsen og udvalgelsen af indikatorer, er der klare udfordringer. Offentlige organisationer varetager vidt forskellige opgaver, og det er ikke alle disse opgaver, hvis resultater er lette at måle (Wilson 1989; de Bruijn 2007). Caroline Howard Grøns artikel illustrerer dette, når pædagogerne skal operationalisere skoleparthed og livsduelighed. Når data skal indsamles og analyseres, kan der også potentielt identificeres barrierer. Siger data noget om effekterne af indsatsen? I Caroline Howard Grøns artikel bliver det klart, at en del af pædagogerne er i tvivl om, hvorvidt man overhovedet kan måle effekten af deres arbejde. Dertil kommer, at det tager tid at indsamle data. I det omfang de relevante aktører ikke kan forstå, hvorfor dataindsamlingen er relevant, bliver det også svært at motivere dem til at gøre det - særligt hvis de i forvejen skal håndtere mange opgaver og har begrænsede ressourcer. 
Også relateret til denne fase har resultatmålingssystemer det med at vokse i omfang. Dette illustreres både i Mads Bøge Kristiansens artikel om udviklingen i det statslige mål- og resultatstyringskoncept, og særligt i interviewet med Stig Henneberg og Nanna Skriver Dall fra Finansministeriet. Resultatmålingssystemer er en måde at reducere kompleksitet på; men reduceret kompleksitet bevirker samtidig et ufuldstændigt billede af de resultater, som en organisation genererer. Der kan derfor fra begge sider af styringsrelationen blive rejst krav om at udvide målingssystemet med henblik på i højere grad at indfange virkeligheden (de Bruijn 2007). Bivirkningen heraf er meget omfattende og omkostningstunge målingssystemer, der desuden kan vanskeliggøre fokus og beslutningstagen for ledelsen.

De næste udfordringer opstår, når den indsamlede information skal anvendes i styringsøjemed. Her er den første risiko, at informationen ikke anvendes aktivt i beslutningsprocessen (jf. delvist artiklerne af henholdsvis Marie-Louise Frølich Brødsgaard og Mathias Gjørling samt Caroline Grøn). Der kan være mange årsager til, at informationen ikke anvendes, men alt andet lige er den reelle anvendelse af resultatinformation en indikator for, hvorvidt resultatstyring er indsatsen værd (Hatry 1999). En væsentlig barriere her kan igen siges at være spørgsmålet om ejerskab/meningstilskrivning. Hvis ikke aktørerne forstår, hvad de skal bruge informationen til, eller de måske synes den er illegitim/af dårlig kvalitet, er det svært at gennemtvinge andet end en overfladisk anvendelse af informationen.

Hvis informationen anvendes, opstår spørgsmålet om, hvad den faktisk anvendes til? Resultatinformation kan anvendes til mange formål, og formålene kan skifte over tid, hvilket fremgår af Mads Bøge Kristiansens artikel. Derudover kan der være forskellige opfattelser af, hvad formålet med resultatstyringen er, ikke mindst mellem forskellige niveauer i styringshierarkiet. Nogle problemer vil formentlig være skabt af, at der kan være ganske store forskelle på den værdi og det formål, som henholdsvis frontlinjen og øvre niveauer i hierarkiet tillægger resultatstyring. Det kan være svært at få det samme værktøj til at fungere lige vel i alle dele af organisationen (jf. artiklen af Marie-Louise Frølich Brødsgaard og Mathias Gjørling). Der er en grundlæggende udfordring for promoveringen af resultatstyring som et styringsregime, der skal gennemsyre hele organisationen, hvis den reelle praksis bliver, at kun dele af organisationen anvender det, da det medfører frustration for begge parter: beslutningstagerne kan blive frustrerede over, at medarbejdere i frontlinjen ikke anvender værktøjet, mens medarbejderne frontlinjen frustreres over, at værktøjet er utilstrækkeligt til deres arbejde. Det peger på, at der er behov for en klar kommunikation om værktøjets formål.

Resultatstyring kan i sådanne tilfælde føre til nogle uheldige adfærdsmæssige ændringer. Adfærdsændringer er hele formålet med styringsredskabet, men det er ikke altid de tiltænkte adfærdsændringer, der følger i kølvandet på et resultatstyringssystem. I litteraturen peges der både på motivationseffekter, idet frontlinjen ikke føler, at målingssystemet tilvejebringer et dækkende billede af de skabte resultater (de Bruijn 2007), og der peges på perverse effekter, såsom målforskydning, tunnelsyn, gaming og snyd (Smith 1995; Bevan \& Hood 2006). Uintenderede adfærdseffekter, der ofte kobles til argumenter om fravær af ejerskab til og mangelfuld meningsskabelse omkring resultatstyringsredskabet. Caroline Howard Grøn fremhæver i sin artikel, at der er stor forskel på, hvordan pædagogerne anvender effektstyring, hvilket medfører en række forskelligartede motivationseffekter. For nogen er det, at de ikke arbejder med værktøjet, i sig selv en kilde til frustration, mens det for andre bibringer en form for kynisme over for det, der kommer „oppefra“. Andre igen tager værktøjet til sig, og der kan konstateres positive motivationseffekter. Igen et godt eksempel på, hvor varieret et styringsredskab kan fortolkes.

Grundlæggende er der altså mange udfordringer i forbindelse med implementeringen af resultatstyring. I lyset af dette fristes man til at spørge, hvorfor promoveringen og anvendelsen af mål- og resultatstyring fortsættes? Der er tydeligvis mange barrierer, og det er svært - hvorfor så blive ved?

Marie-Louise Frølich Brødsgaard og Mathias Gjørling argumenterer i artiklen om 6-by-samarbejdet, som nævnt, for, at den fortsatte anvendelse skyldes efterspørgsel fra en gruppe af eliteaktører, der har tilstrækkelig indflydelse til at kræve fortsættelsen af anvendelsen. Det er svært at sige, om denne gruppe primært efterspørger brugen af resultatstyring ud fra en konsekvenslogik eller ud fra en legitimitetslogik, men eftersom det er svært at påvise store styringsmæssige gevinster, er det sværere at forsvare konsekvenslogikken. Det peger således på, at der $i$ et vist omfang er tale om legitimitetsstrategi.

Derudover kunne man med rette vende tilbage til udgangspunktet; det er faktisk ikke så let at styre. Flere af artiklerne i dette temanummer stiller spørgsmålstegn ved, om resultatstyring har indfriet de store forventninger, og påpeger i højere grad udfordringer og barrerier ved resultatstyring frem for at fortælle succeshistorier. På trods af dette er formålet med temanummeret imidlertid ikke at forkaste resultatstyring som et anvendeligt styringsredskab i den offentlige sektor. Formålet er snarere at opfordre til refleksion over, hvor og hvordan man meningsfuldt anvender resultatstyring i den offentlige 
sektor. Derudover er formålet at mane til besindighed og opfordre til mere realistiske forventninger til, hvad resultatstyring kan levere. Der vil formentlig være udfordringer og barrierer ved anvendelsen af ethvert styringsredskab. Det vil derfor afslutningsvist i denne indledning være rimeligt at påpege, at de færreste styringsværktøjer leverer $100 \%$ af, hvad de, eller de, der foreslår dem, lover. Dette gælder også for resultatstyring. Resultatstyring flytter måske ikke bjerge i den offentlige sektor, men hvis erkendelsen i den offentlige sektor er, at det flytter lidt, så er det vel bedre end ingenting?

\section{Litteratur}

Bevan, G. \& C. Hood 2006, 'What's Measured is what Matters: Targets and Gaming in the English Public Health Care System', Public Administration, vol. 84, no. 3, pp. 517-534.

Brunsson, N. 2000, The Irrational Organisazation. Irrationality as a basis for organizational action and change, Fagbokforlaget, Bergen.

Brunsson, N. 2002, The Organization of hypocrisy. Talk, decisions and Actions in Organizations, Abstrakt forlag, København.

Czarniawska, B. \& G. Sevón, eds., 1996, Translating organisational change, de Gruyter, Berlin.

De Bruijn, H. 2007, Managing Performance in the Public Sector, Routledge, London.

Dixit, A. 2002, 'Incentives and Organizations in the Public Sector. An Interpretive Review', Journal of Human Resources, vol. 37, no. 4, pp. 696-727.

Galbraith, J.R. 1977, Organization Design, Addison-Wesley Publishing Company, Massachusetts.

Hatry, H. 1999, Performance Measurement. Getting Results, Urban Institute Press, Washington.

Hood, C. 2007, 'Public Service Management by Numbers: Why Does it Vary? Where has it Come From? What Are the Gaps and the Puzzles?', Public Money and Management, vol. 27, no.2, pp. 95-102.

Kristiansen, M.B., red., 2014, Resultatstyring i den offentlige sektor. Jurist- og Økonomforbundets Forlag, København.

Meyer, J.W. \& B. Rowan 1977, 'Institutionalized Organizations: Formal Structure as Myth and Ceremony', American Journal of Sociology, vol. 83, no.2, pp. 340-363.

Pollitt, C. \& G. Bouckaert 2011, Public Management Reform: A Comparative Analysis, 3. edn., Oxford University Press, Oxford.

Pollitt, C. 2001, 'Convergence; the Useful Myth?', Public Administration, vol. 79, no. 4, pp. 933-947.

Pollitt, C. 2002, 'Convergence - Striking similarities and durable differences in public management reform', Public Management Review, vol. 4, no. 1, pp. 471-492.

Produktivitetskommissionen 2014, Det handler om velferd og velstand. Slutrapport, Produktivitetskommissionen, København.
Radin, B.A. 2006, Challenging the Performance Measurement: Accountability, Complexity, and Democratic Values, Georgetown University Press, Washington.

Regeringen 2011, Et Danmark der står sammen, Regeringsgrundlag oktober 2011, Regeringen, København.

Regeringen 2013, Vakstplan DK. Sterke virksomheder, flere job, Regeringen, København.

Regeringen 2014, Det nationale reformprogram. Danmark 2014, Regeringen, København.

Rittel, H.W.J. \& M.M. Webber 1973, 'Dilemmas in a General Theory of Planning', Policy Sciences, vol. 4, pp. 155-169.

Røvik, K.A. 2007, Trender og Translasjoner. Ideer som former det 21. århundrets organisasjon, Universitetsforlaget, Oslo.

Scott, W.R. \& G.F. Davis 2007, Organizations and organizing: rational, natural, and open systems perspectives, Pearson Prentice Hall, Upper Saddle River.

Smith, P. 1995, 'On The Unintended Consequences of Publishing Performance Data in the Public Sector', International Journal of Public Administration, vol. 18, no. 2, pp. 277-310.

Weber, M. 1968, Gesammelt Aufsätze zur Wissenschaftslehre, 3. edn,. J.C.B. Mohr, Tübingen.

Weick, K.E. 2001, Making Sense of the Organization, Blackwell Publishers, Malden MA.

Wilson, J.Q. 1989, Bureaucracy: What Government Agencies Do and Why They Do It, Free Press, New York.

\section{Noter}

1. Moderniseringsprogrammet kan findes her: http://www.denoffentlige.dk/aktorhistorier/historisk-regeringens-moderniseringsprogram-fra-1983

2. Her er det måske væsentligt at klargøre at forskellen mellem mål og resultater. VI taler om resultatstyring i dette temanummer, men når vi beskriver organisationer som målorienterede skal det forstås i forlængelse af organisationsteoriens diskussion af organisationers forhold til mål (fx Scott \& Davies, 2007). Ved målorientering skal forstås at organisationer generelt er orienterede mod generelle formelle mål, i modsætning til fx uformelle mål eller primært overlevelse.

3. Vi vælger her at forstå styringsopskrift som en relativt abstrakt beskrivelse af, hvordan organisationer styrer på den mest hensigtsmæssige måde.

4. Vi er klar over at Røvik teoretisk positionerer sig i opposition til tanken om afkobling. Imidlertid opererer han med et implementeringsoutcome, der hedder frikopling (Røvik, 2007: 320), som er lig det, de sociologiske institutionalister kalder afkobling.

5. Carsten Jarlov var direktør i Bygningsstyrelsen, da interviewet blev gennemført, men gik bort i december 2014.

6. Stig Henneberg er pr. 1. januar 2015 blevet afdelingschef for Offentlige finanser og vækst og konkurrence i Finansministeriet. 